Artikel Penelitian

\title{
Aktivitas Antibakteri Ekstrak Etanol Herba Apu-Apu (Pistia stratiotes) terhadap Staphylococcus aureus
}

Dewi Dianasari $^{* 1}$, Maulidya Barikatul Iftitah ${ }^{2}$

1,2 Fakultas Farmasi, Universitas Jember, Jember,

Indonesia (dewi.dianasari@unej.ac.id,081933300910)

\begin{abstract}
ABSTRAK : $S$. aureus merupakan salah satu bakteri gram positif yang dapat menyebabkan infeksi bernanah, infeksi kulit ataupun infeksi serius seperti mastitis, pneumonia dan infeksi saluran kencing. Penemuan senyawa aktif baru berasal dari tumbuhan merupakan potensi alternatif sebagai agen antibakteri. Salah satunya ialah tanaman dengan famili Araceae dari genus Pistia yaitu Pistia stratiotes atau yang biasa dikenal dengan sebutan apu-apu. Penelitian ini dilakukan untuk membuktikan secara ilmiah adanya aktivitas antibakteri dari ekstrak etanol herba apu-apu (Pistia stratiotes) terhadap Staphylococcus aureus. Uji antibakteri dengan metode difusi cakram dilakukan pada 6 kelompok, yaitu 4 kelompok perlakuan ekstrak etanol herba apu-apu dengan berbagai konsentrasi $(10 \% ; 20 \%$; 30\%; dan 40\%), satu kelompok uji berisi kontrol negatif yaitu DMSO 10\%, dan satu kelompok uji lainnya berisi kontrol positif yaitu

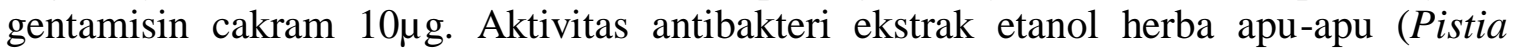
stratiotes) terhadap $S$. aureus dari yang tinggi ke rendah secara berurutan adalah konsentrasi $40 \%$, konsentrasi 30\%, konsentrasi 20\%, konsentrasi $10 \%$ dengan nilai diameter zona hambat berturut-turut sebesar $9,0 \mathrm{~mm} \pm 0,30 ; 8,1 \mathrm{~mm} \pm 0,20 ; 7,4 \mathrm{~mm} \pm$ 0,33; dan 6,5 $\mathrm{mm} \pm 0,17$. Berdasarakan hasil penelitian, maka dapat disimpulkan bahwa ekstrak etanol herba apu-apu pada konsentrasi 10\%; 20\%; 30\%; dan 40\% memiliki aktivitas antibakteri terhadap $S$. aureus.
\end{abstract}

\section{Kata kunci: Antibakteri, herba apu-apu, difusi cakram}

ABSTRACT: Staphylococcus aureus is one of the gram-positive bacteria that can cause festering infections, skin infections or serious infections such as mastitis, pneumonia and urinary tract infections. The discovery of new active compounds derived from plants is an alternative potential as an antibacterial agent. One of them is a plant with the family Araceae of the Pistia genus, Pistia stratiotes (apu-apu). This research was conducted to scientifically prove the antibacterial activity of the ethanol extract of apu-apu herbal against Staphylococcus aureus. Antibacterial test using the disk diffusion method was carried out in 6 groups, namely 4 treatment groups of apu-apu herbal ethanol extract (10\%; 20\%; 30\%; and 40\%), one test group contained negative controls (DMSO 10\%), and one other test group contained positive controls (10 $\mu \mathrm{g}$ gentamicin disk). The antibacterial activity of this research from high to low in sequence is a concentration of $40 \%, 30 \%, 20 \%$, and $10 \%$ with a diameter value of inhibitory zones successively at 9, 0 $m m \pm 0.30 ; 8.1 \mathrm{~mm} \pm 0.20 ; 7.4 \mathrm{~mm} \pm 0.33$; and $6.5 \mathrm{~mm} \pm 0.17$. Based on the results of the study, it can be concluded that the ethanol extract of apu-apu herbal at a concentration of 10\%; 20\%; 30\%; and 40\% have antibacterial activity against S. aureus.

Keywords: antibacterial, apu-apu herb, disk diffusion 


\section{Artikel Penelitian}

\section{PENDAHULUAN}

Penyakit infeksi merupakan salah satu jenis penyakit yang paling banyak diderita oleh masyarakat di negara berkembang seperti Indonesia. ${ }^{1}$ Adanya mikroorganisme patogen seperti virus, jamur atau parasit, dan bakteri merupakan penyebab terjadinya infeksi. ${ }^{2}$ Salah satu jenis infeksi yang dikenal ialah infeksi nosokomial yaitu infeksi yang diperoleh seseorang selama di rumah sakit.

Staphylococcus aureus merupakan bakteri penyebab infeksi nosokomial yang banyak terjadi di Indonesia. S. aureus adalah patogen utama pada manusia dari spesies genus Staphylococcus yang lain, serta merupakan penyebab utama infeksi nosokomial akibat luka bedah dan infeksi yang berhubungan dengan penggunaan alat-alat medis. S. aureus merupakan salah satu bakteri gram positif yang dapat menyebabkan infeksi bernanah, infeksi kulit ataupun infeksi serius seperti mastitis, pneumonia dan infeksi saluran kencing. ${ }^{3}$

Penemuan senyawa aktif baru berasal dari tumbuhan merupakan potensi alternatif sebagai agen antibakteri. ${ }^{4}$ Banyak penelitian mengenai penggunaan tumbuhan obat sebagai antibakteri, ${ }^{5}$ namun yang memiliki aktivitas farmakologis yang baik sebagai antibakteri hanya sedikit. ${ }^{6}$ Indonesia memiliki kekayaan keragaman hayati terbanyak kedua di dunia, namun hanya sekitar 200 spesies yang sudah diteliti potensinya sebagai sumber agen anti infeksi. ${ }^{7}$ Hal ini menunjukkan bahwa penelitian tumbuhan obat Indonesia perlu dikembangkan untuk mengetahui potensi keanekaragaman hayati di Indonesia, sehingga dapat dimanfaatkan sebagai agen antibakteri. Salah satunya ialah tanaman dengan famili Araceae dari genus Pistia yaitu Pistia stratiotes atau yang biasa dikenal dengan sebutan apu-apu.

Apu-apu (Pistia stratiotes) merupakan gulma air yang memiliki daun berwarna hijau kebiruan berbentuk seperti mawar. ${ }^{8}$ Daun apu-apu telah digunakan sebagian masyarakat untuk mengobati demam, batuk rejan, flu, radang, serta penyakit kulit seperti bisul dan eksim.$^{9}$ Tumbuhan apu-apu memiliki kandungan metabolit sekunder seperti flavonoid, fenol, saponin, tanin, steroid dan alkaloid. Kandungan senyawa ini diduga memiliki aktifitas antioksidan dan antibakteri. ${ }^{10}$ 


\section{Artikel Penelitian}

Berdasarkan uraian di atas, maka perlu dilakukan penelitian lebih lanjut untuk membuktikan secara ilmiah adanya aktivitas antibakteri dari ekstrak etanol herba apuapu (Pistia stratiotes) terhadap Staphylococcus aureus. Ekstrak akan diuji aktivitas antibakterinya menggunakan metode difusi cakram.

\section{BAHAN DAN METODE}

Penelitian yang dilakukan merupakan true experimental laboratories, yang dilakukan di Laboratorium Mikrobiologi dan Bioteknologi bagian Biologi Farmasi serta Laboratorium Analisis Instrumen Fakultas Farmasi Universitas Jember mulai bulan April hingga Juli 2019. Alat yang digunakan antara lain: timbangan analitik (Sartonius CP224S), oven (Memmert), blender, rotary evaporator (Heidolph), seperangkat alat gelas, jarum ose, bunsen, pinset, loyang, spatula logam, magnetic stirrer, hotplate, kertas saring, microtube, microtip, autoklaf (ALP), vortex (Labnet), micropipet (Socorex), jangka sorong, waterbath, alumunium foil (Klin- pak), inkubator (Gallenkamp) dan laminar air flow (Airtech). Sedangkan bahan yang digunakan antara lain: tumbuhan apuapu (Pistia stratiotes) yang diperoleh dari wilayah Kabupaten Jember, Mueller Hinton Agar (MHA), Nutrient Agar (NA), S. aureus ATCC 33591, etanol 96\%, akuades steril, $\mathrm{NaCl}$ 0,9\%, larutan Mc Farland 0,5, DMSO, gentamisin cakram10 $\mu \mathrm{g}$.

Ekstraksi simplisia herba apu-apu dilakukan dengan metode maserasi selama 3 hari menggunakan pelarut etanol 96\% (1:10). Ekstrak yang didapat dihitung jumlah rendemennya. Uji aktivitas antibakteri dilakukan dengan menggunakan metode difusi cakram pada media MHA. Uji antibakteri dengan metode difusi cakram dilakukan pada 6 kelompok, yaitu 4 kelompok perlakuan ekstrak etanol herba apu-apu dengan berbagai konsentrasi (10\%; 20\%; 30\%; dan 40\%), satu kelompok uji berisi kontrol negatif yaitu DMSO 10\%, dan satu kelompok uji lainnya berisi kontrol positif yaitu gentamisin cakram $10 \mu \mathrm{g}$. Media bakteri yang sudah diberi kontrol serta perlakuan diinkubasi pada suhu $37^{\circ} \mathrm{C}$ selama 21 jam. Diameter zona hambat yang terbentuk diukur dengan jangka sorong untuk menentukan efektivitas dari antibakteri. Pengujian dilakukan sebanyak 3 kali. Data hasil uji aktivitas tersebut kemudian dianalisis menggunakan One way Anova dan dilanjutkan dengan post hoc test. 


\section{Artikel Penelitian}

\section{HASIL}

Berdasarkan hasil pengujian aktivitas antibakteri (Tabel 1) aktivitas antibakteri ekstrak etanol herba apu-apu (Pistia stratiotes) terhadap S. aureus dari yang tinggi ke rendah secara berurutan adalah konsentrasi 40\%, konsentrasi 30\%, konsentrasi $20 \%$, konsentrasi $10 \%$ dengan nilai diameter zona hambat berturut-turut sebesar 9,0 $\mathrm{mm} \pm$ 0,$30 ; 8,1 \mathrm{~mm} \pm 0,20 ; 7,4 \mathrm{~mm} \pm 0,33$; dan $6,5 \mathrm{~mm} \pm 0,17$. Kontrol negatif yang digunakan yaitu DMSO 10\%, yang menunjukkan tidak memberikan aktivitas antibakteri yang dapat mempengaruhi kemampuan ekstrak, yaitu ditandai dengan hasil pada diameter zona hambat sebesar $0,00 \mathrm{~mm}$. Sedangkan kontrol positif yang digunakan yaitu gentamisin 10 $\mu \mathrm{g}$, memberikan zona hambat sebesar 19,3 $\mathrm{mm} \pm 0,30$ terhadap bakteri $S$. aureus.

Tabel 1. Hasil Pengamatan Diameter Zona Hambat Ekstrak Etanol Herba Apu- apu terhadap Bakteri S. aureus

\begin{tabular}{|c|c|}
\hline Kelompok Uji & $\begin{array}{c}\text { Rata-rata Diameter Zona } \\
\text { Hambat }(\mathrm{mm}) \pm \mathrm{SD}\end{array}$ \\
\hline Ekstrak $(10 \% \mathrm{~b} / \mathrm{v})$ & $6,5 \pm 0,17^{\mathrm{a}}$ \\
\hline Ekstrak $(20 \% \mathrm{~b} / \mathrm{v})$ & $7,4 \pm 0,33^{\mathrm{V}}$ \\
\hline Ekstrak $(30 \% \mathrm{~b} / \mathrm{v})$ & $8,1 \pm 0,20^{\mathrm{C}}$ \\
\hline Ekstrak $(40 \% \mathrm{~b} / \mathrm{v})$ & $9,0 \pm 0,30^{\mathrm{d}}$ \\
\hline Kontrol + (gentamisin 10 $\mu \mathrm{g})$ & $19,3 \pm 0,30^{\mathrm{e}}$ \\
\hline Kontrol - (DMSO 10\%) & 0,00 \\
\hline
\end{tabular}

Notasi huruf yang berbeda ,menunjukkan adanya perbedaan yang signifikan antar kelompok berdasarkan hasil analisis post hoc test $(\mathrm{p}<0,05)$

Sumber: Data primer, 2019

Gambar 1. Aktivitas Antibakteri Ekstrak Etanol Herba Apu-apu terhadap Bakteri S. aureus ATCC 33591 dengan Metode Difusi Cakram

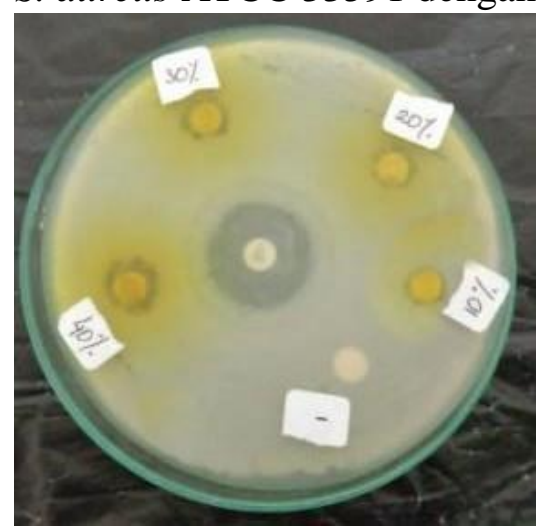

Sumber: Data primer,2019 
Artikel Penelitian

Data hasil pengujian aktivitas antibakteri masing-masing ekstrak dianalisis secara statistik. Berdasarkan uji normalitas dan homogenitas yang dilakukan, diperoleh nilai signifikansi p>0,05 yang menunjukkan bahwa data terdistribusi normal dan homogeny. Data hasil pengujian aktivitas antibakteri kemudian dilanjutkan menggunakan uji lanjutan statistik One Way ANOVA. Dari hasil analisis One Way ANOVA yang telah dilakukan diperoleh $\mathrm{p}=0,000$, dan dilanjutkan uji post hoc dengan hasil $\mathrm{p}<0,05$ untuk semua kelompok uji dibandingkan dengan kelompok kontrol negatif (DMSO10\%).

\section{PEMBAHASAN}

Pada penelitian ini digunakan metode ekstraksi maserasi. Ekstrak herba apu-apu diekstraksi dengan metode maserasi menggunakan pelarut etanol. Rendemen ekstrak didapatkan dari hasil perbandingan massa ekstrak kering yang diperoleh dibagi dengan massa serbuk herba apu-apu dikalikan 100\%. Massa ekstrak kering yang diperoleh yaitu 24,53 gram, sehingga rendemen ekstrak yang didapatkan yaitu 12,5\%.

Metode pengujian antibakteri yang digunakan pada penelitian ini yaitu metode difusi cakram. Metode difusi cakram dipilih karena penelitian ini merupakan skrining awal untuk mengetahui aktivitas antibakteri suatu larutan uji. Selain itu, uji aktivitas antibakteri menggunakan metode difusi lebih sederhana dan mudah dibandingkan dengan metode uji lain. ${ }^{11}$ Ekstrak etanol herba apu-apu diketahui memiliki aktivitas antibakteri ditunjukkan dengan adanya zona bening di sekitar cakram (Gambar 1).

Pada uji aktivitas antibakteri ekstrak etanol herba apu-apu, kontrol positif gentamisin menunjukkan aktivitas antibakteri pada S.aureus dan DMSO 10\% sebagai kontrol negative tidak memberikan aktivitas antibakteri. Sedangkan ekstrak etanol herba apu-apu memiliki aktivitas antibakteri terhadap S. aureus. Aktivitas antibakteri terbesar ada pada ekstrak uji dengan konsentrasi 40\% dengan diameter zona hambat 9,0 $\mathrm{mm} \pm 0,20$ dan aktivitas antibakteri terkecil ada pada ekstrak uji dengan konsentrasi $10 \%$ dengan rerata diameter zona hambat $6,5 \mathrm{~mm} \pm 0,17$. Berdasarkan analisis statistik yang telah dilakukan (Tabel 1.) dapat dilihat bahwa terdapat perbedaan bermakna aktivitas antibakteri $S$. aureus pada semua kelompok uji pada berbagai konsentrasi dibandingkan dengan kelompok kontrol negatif (DMSO 10\%). 


\section{Artikel Penelitian}

Hal itu menunjukkan bahwa ekstrak etanol herba apu-apu memiliki aktivitas antibakteri terhadap $S$. aureus. Dari Tabel 1. dapat dilihat bahwa semakin besar konsentrasi ekstrak maka besar diameter zona hambat yang dihasilkan juga semakin besar, diduga hal tersebut karena senyawa aktif yang berfungsi sebagai antibakteri pada ekstrak juga semakin banyak.

Senyawa kimia yang diduga berperan dalam aktivitas antibakteri pada ekstrak etanol herba apu-apu antara lain flavonoid, saponin, polifenol, terpenoid, dan steroid . Flavonoid telah diketahui memiliki respon terhadap bakteri. Kemampuan aktivitasnya membentuk kompleks dengan protein seluler dan dinding sel bakteri. ${ }^{12}$ Golongan senyawa saponin sebagai antibakteri yang dapat menyebabkan terganggu permeabilitas dinding sel bakteri. ${ }^{13}$ Polifenol dalam penghambatan pertumbuhan atau mematikan bakteri berhubungan dengan penghambatan enzim hidrofilik (protease dan karbohidrolase). ${ }^{14}$ Terpenoid dapat berperan sebagai antibakteri dengan menyebabkan kebocoran membran dinding sel oleh senyawa lipofilik (kebocoran protein) sehingga dinding sel tidak terbentuk sempurna. ${ }^{12,15}$ Mekanisme steroid sebagai antibakteri dengan berinteraksi dengan membran fosfolipid sel sehingga menyebabkan kebocoran liposom bakteri. ${ }^{16}$

\section{KESIMPULAN DAN SARAN}

Berdasarkan hasil penelitian dapat diambil kesimpulan bahwa aktivitas antibakteri ekstrak etanol herba apu-apu (Pistia stratiotes) terhadap S. aureus dari yang tinggi ke rendah secara berurutan adalah konsentrasi 40\%, konsentrasi 30\%, konsentrasi $20 \%$, konsentrasi $10 \%$ dengan nilai diameter zona hambat berturut-turut sebesar 9,0 $\mathrm{mm} \pm$ 0,$30 ; 8,1 \mathrm{~mm} \pm 0,20 ; 7,4 \mathrm{~mm} \pm 0,33$; dan $6,5 \mathrm{~mm} \pm 0,17$. Adapun saran untuk penelitian ini adalah diperlukan adanya penelitian lanjutan mengenai aktivitas antibakteri ekstrak herba apu- apu terhadap bakteri lain ,senyawa aktif spesifik ekstrak herba apu-apu yang berpotensi terhadap aktivitas antibakteri, dan perlu dilakukan penelitian lebih lanjut untuk skrining fitokimia dan uji aktivitas antibakteri dari fraksi herba apu-apu.

\section{UCAPAN TERIMAKASIH}

Ucapan terimakasih, penulis sampaikan kepada Fakultas Farmasi Universitas Jember yang telah memfasilitasi terlaksananya penelitian ini, 
Artikel Penelitian

\section{DAFTAR PUSTAKA}

1. Radji, M. 2011.Mikrobiologi Panduan Mahasiswa Farmasi \& Kedokteran. Jakarta: EGC.

2. WHO. $2016 . \quad$ WHO Infectious Diseases. http://www.who.int/topics/infectious_diseases/en/ [Diakses pada April 15,2019].

3. Todar, K. 2008. Staphylococcus aureus and Staphylococcal Disease.

4. Wagner, H. dan Ulrich-Merzenich, G., 2009. Synergy Research: Approaching a New Generation of Phytopharmaceuticals. Phytomedicine: international journal of phytotherapy and phytopharmacology, 16: 97-110.

5. Tanaka, J.C.A., C.C. da Silva, A.J.B. de Oliveira, C.V. Nakamura dan B.P. Dias Filho. 2006. Antibacterial activity of indole alkaloids from Aspidosperma ramiflorum. Braz J Med Biol Res.

6. Gibbons, S. 2003. An overview of plant extracts as potential therapeutics. Expert Opinion on Therapeutic Patents. 13(4):489-497.

7. Keller, P. A. dan A. S. Nugraha. 2011. Revealing indigenous indonesian traditional medicine: anti-infective agents. Natural Product Communications. 6(12):1953-1966.

8. Wirawan, Wiweka A., Ruslan W., Liliya DS. 2014. Pengolahan Limbah Cair Domestik Menggunakan Tanaman Kayu Apu (Pistia Stratiotes L.) dengan Teknik Tanam Hidroponik Sistem DFT (Deep Flow Technique). Jurnal Sumberdaya Alam Dan Lingkungan, 1, 63-70.

9. Dalimartha, S. 2007. Atlas Tumbuhan Obat Indonesia Jilid IV. Jakarta: Puspa Swara.

10. Wasahla. 2015. Analisis senyawa fitokimia dan aktivitas antioksidan ekstrak tumbuhan apu-apu (Pistia stratiotes), Skripsi. (Tidak dipublikasikan). Indralaya: Fakultas Pertanian, Universitas Sriwijaya.

11. Balouiri, M., M. Sadiki, dan S. K. Ibnsouda. 2016. Methods for in Vitro Evaluating Antimicrobial Activity: a review. Journal of Pharmaceutical Analysis. 6(2):71-79.

12. Cowan, M. M, 1999. Plants Products as Antibacterial Agents. Clin. Microbiol. Rev. 1999, 12(4):564.

13. Arabski, M., Ciuk, A.N., Czerwonka, G., Lankoff, A., dan Kaca, W. 2012. Effect of saponin against clinical $E$. coli strain and eukaryotic cell line. Journal of Biomedicine and Biotechnology,12.

14. Karou, D., M.H. Dicko, J. Simpore dan A.S. Traore, 2005. Antioxidant andantibacterial activities of polyphenols from ethnomedicinal plants of Burkina Faso. Afr. J. Biotechnol., 4: 823-828.

15. Bama, S.S., Sankaranarayan, S., Kingsley,S. J., dan Bama, P. 2012. Antibacterial activity of different phytochemical extracts from the leaves of T. procumbens Linn.: Identification and mode of action of the terpenoid compound as antibacterial. International Journal of Pharmacy and Pharmaceutical Sciences, 4:557-564.

16. Madduluri,S., Rao, K.B., dan Sitaram, B. In vitro Evaluation of Antibacterial Activity of Five Indigenous Plants Extract Against Five Bacterial Pathogens of Human. Int J Pharm Pharm Sci, Vol 5 (4): 679-684. 